\title{
Significance of the Theme of Death in Crossover Literature: A Case Study of Harry Potter and The Boy in the Striped Pyjamas
}

\author{
Muqi Cheng \\ Beijing Language and Culture University, Beijing 100083, China \\ Email: maxinecheng2020@163.com
}

\begin{abstract}
Death is the inevitable status of life, and every individual must conform to the rule of nature. Naturally, literature works at all times incline to involve death as an eternal theme that worth deeper thinking and reflection. Crossover literature, now gaining increasing popularity, is no exception. Boyd Tonkin nicely encapsulates the working definition of crossover fiction: "a crossover novel is one 'ostensibly written for children' which 'adults should read too"” (Tonkin 6). It blurs the borderline between traditionally separate readerships: children and adults. In different literature genres, discussions about the theme of death offer readers different reading experience, which largely determined by the manner in which the writers present it. There are some common ways to refer to this topic, For example, by poetically beautifying death as a symbol of getting rid of the pangs in real world, or directly depicting the detailed experience of death. However, considering the specialty of readerships of crossover literature, writers must handle their discussion on death carefully to satisfy the two different target audience groups — both children and adults. They differ in intelligence, values and life experiences, which lead to very divergent perspectives and preferences for books.

The thesis explores two pieces of typical crossover literature work, Harry Potter series and The Boy in the Striped Pyjamas. Both of them are influential worldwide, attracting numerous readers of all ages. I concentrate primarily on the author's portrayal of and reflection on the theme of death, also its profound influence exerted on readers.
\end{abstract}

Keywords: crossover fiction, death

\section{Literature review}

Harry Potter and The Boy in the Striped Pyjamas are two crossover fictions that have found immense popularity worldwide, attracting a wide adult audience as well as younger readers. It is worth noticing that death is involved in both novels as a crucial topic. Nevertheless, the two fictions, since originally written for children, have arouse doubts in terms of their depiction of death.

Nagy.M convincingly refutes the opinion that considering the vulnerability of children — one of the target audience of crossover fictions, crossover writers should shield them from death and its textual representations. She provides statistics to prove children's cognitive readiness of understanding death, and claimed that at the age of 3 children are able to perceive death, and till 9 years old such understanding is basically complete. (73) Domestic researcher Chen Junjun also argues that when children are included in the target audience, it is the duty for literature work to involve death when needed, thus correctly guide young readers and help establish correct view of life and death. (109) I strongly agree with their opinions that death should not be treated as a taboo in crossover that aims for both children and adults. While adhering to honesty, Rowling and Boyne employ unique depictions that are suitable for readers of all age, simultaneously, infusing their deep reflections thus exerting profound influence on both children and adult readers.

\section{Thesis statement}

Due to the large readership that includes both children and adult, crossover literature has its particularity in writer's portrayal of the theme of death. This thesis is a case study of two typical crossover fictions, in terms of their different portrayal of death and its influence exerted on the large readership. Harry Potter is a close examination of the young hero's gradual maturity prompted by experiences of departure of the loved ones. Rowling utilizes symbolic image, tender depiction of "returning", as well as the progressive narrative style with respect to the hero's acceptance of the nature of death, thus revealing guiding functions for youngsters. Boyne's The Boy in the Striped Pyjamas depicts death and gloomy symbols of warfare with full employment of children's perspective and euphemistic language, thus specifically inspiring mature readers to reflect upon the dark side of humanity. Both the two fictions demonstrate unique reflections on death, but with different means of portrayal. They successfully exert profound influence on children and adult readers. 


\section{Topic ideas}

\subsection{Rowling's portrayal of death}

\subsubsection{The "returning", symbolic image and progressive narrative style}

J.K. Rowling's Harry Potter novels enjoy global popularity. It seems that, Hogwarts, the magic world she created, is miraculous enough with all the stunning imaginative details. But the most significant feature is that it is not too ideal to be connected with reader's realistic world. Readers indeed gain access to a new world, where people scarcely be bothered by depressing troubles in real world. One can fix any gadgets or clean up the room with a spell, even ride on a broomstick to anywhere they want. Nevertheless, realistic issues like bullying and strict school punishment system still exist. Most importantly, death, even for wizards, is still inevitable, echoing the eternal dismay of mankind. Therefore, both adult and children readers can still feel a sense of reality that functions as a bridge, connecting the magic world with real world.

It would seem obvious, to anyone who has read it, that death exists as a prominent element. In fact, Harry Potter series feature death from the very beginning. Knowing the prophecy that Harry is destined to thwart the him, the wickedest wizard Voldemort attempts to kill Harry in his infancy. Although Harry survives the killing curse, his parents died protecting him.

Death in Potter novels still keeps its basic features of being universal and irreversible. However, Rowling demonstrates it in a unique way by introducing the concept of "returning". Moreover, by employing narrative designs and poetic images, her reflection on death not only retains an aura of magic and mystery, but also makes the heavy theme reveal itself in a less painful manner. As a result, readers are able to view death from a comforting perspective. Furthermore, the function of the death becomes multilayered in this novel as a combination of characterization force as well as educational theme.

Unlike the case in real world scenario, that a person dies does not necessarily imply that the person is gone forever. "Once the reader has been drawn into the realm of Hogwarts, s/he learns not to conceive of death in binary terms. 'Dead' and 'alive' are not mutually exclusive antonyms"(Andrea Stojilkov 135). In Harry Potter, it can be found that the dead may "return" in the forms of reflections and illusions.

In Harry Potter and the Sorcerer's Stone (Rowling), Harry "reunites" with his parents through the reflections in the mirror of Erised. Behind his reflection, his parents "was smiling at him and waving", Harry was so eager to meet them that "he was hoping to fall right through it and reach them". He could hardly deal with the terrible sadness, and was overwhelmed by "a powerful kind of ache inside him" (Sorcerer's Stone 166). James and Lily Potter "return" though in the form of vague reflections, but their loving image and tenderness for Harry can still be perceived by readers. In this initial stage, Harry is desperate to escape from the reality of death, and nearly "dwells on dreams and forgets to live". (Sorcerer's Stone 167). He was paralyzed and could not do away with the extreme sorrow brought by their death.

As Harry experiencing his growth in the novel, his view of death is in transition as well. Specifically, another "returning" that occurs in Harry Potter and the Prisoner of Azkaban (Rowling) is worth exploring. Patronus, a very typical example of Rowling's original mythical elements (Hiebert Alton 220), is introduced and further elaborated on its connection with understanding death. Patronuses are protectors of the spirit, guardians of the souls and antidotes against Dementors (dark creatures that feed on human happiness and thus generate feelings of despair.) Despite his effort, the gloom of death still hangs over him and weakens his spirit, hindering him from conjuring his patronus. "something else kept intruding.... Any second now, he might hear his mother again... but he shouldn't think that, or he would hear her again, and he didn't want to... or did he" (Azkaban 197). When he was attacked by the dementors, the patronus generated from his positive emotions was too weak to defend himself. The evil creature "made a gesture" and easily "swept the Patronus aside" (322). However, in the critical moment appeared "a silvery light growing brighter and brighter" (323), A "real" and "powerful" (343) Patronus rescued him.

The mysterious rescuer put Hurry again in painful internal struggle. When he seemed firm to accept the truth of death: “"They're dead,' he told himself sternly. 'They're dead and listening to echoes of them won't bring them back"' (202). But he could not help being swayed by his wistful illusions and denial of death. Harry believed that his father must have "returned" to protect him, and the vague image shall be the perfect evidence of his presence.

With the suspense developed, he had gone back in time to find his father, when "It was time for the rescuer to appear.. but no one was coming to help this time... And then it hit him... he understood. He hadn't seen his father... he had seen himself..." (347). This epiphany indicates that he is finally courageous enough to confront with the nature of life and death, and could walk out of the gloom peacefully. With the internal struggle settled, he regains spiritual power strong enough to conjure a splendid Patronus, "out of the end of his wand burst, not a shapeless cloud of mist, but a blinding, dazzling, silver animal." "It was galloping around and around the black shapes on the ground, and the Dementors were falling back, 
scattering, retreating into the darkness... They were gone" (347).

Though eventually it turns out to be a imaginary "returning" of the loved one, such crafted design immensely promotes Harry's psychological development.

\subsubsection{Influence of Rowling's portrayal of death}

In Erikson's Psychological Development theory, he separates one's life into eight epigenetic stages. "Each stage represents a critical period of conflict and possible crisis". And stages are usually "defined by crises, each one driven by internal conflict, typical for a particular developmental period" (Svetina. M 394). Death is obviously one extreme crisis. Presenting the process of addressing and accepting the nature of death can facilitate the maturity of both the hero and younger readers.

Firstly, it can be found that Rowling employs numerous tender depictions of the "returning" of Harry's deceased parents. More importantly, the progressive narrative style with respect to the hero's acceptance of nature of death is more accessible for young readers (Zhang Yingming 28). Each time the "returning" offers Harry a deeper understanding of death. Along with Harry, children experience similar emotional process, from sadness and escapism to eventually learning to accept it with a positive attitude, accomplishing the advancement in psychological maturity.

In addition, inventing Patronus as animal-shaped guardian angels not only implies deep symbolism (Stojilkov 139), but also reveals the idea that eternal bond of love can prevail death. Gail Orgelfinger praises that Rowling made good use of the values of various real and mythical animals in medieval bestiaries. (141). The stag (Harry's and his father's Patronus) is the ultimate rival of the snake (a fragment of Voldemort's soul is hidden in it). Most importantly, as what Dumbledore said to Harry, "in a way, you did see your father last night... You found him inside yourself" (Azkaban 362). Harry and his father had the same Patronus, which functions as a poetic symbol that allows young readers to perceive a concrete and visualized emotional bond between them.

Rowling never makes mortality a tragic end or a mournful consequence, but ultimately connects it with love. Her novels emphasize that the deceased we love never truly leave us. They live in the heart of those who remember them as inseparable parts, endowing the living people with eternal love and strength. Love, in Harry Potter, manifests itself by visualized forms of "returning" of the deceased ones, or the splendid patronuses that are stronger than the darkest magic, and even death. She makes sure that her faith is clearly conveyed to her readers, especially the innocent youngsters among them: Love transcends death. It stays with us even though the physical body may perish one day. Such profound reflections can be inspiring for both adults and children. Therefore, it is essential to find oneself the power of love and bravely go forward with it.

\subsection{Boyne's portrayal of death and gloomy symbols}

\subsubsection{Children's perspective and euphemism}

John Boyne's novel The Boy in the Striped Pyjamas is a crossover literature originally written for children, but it also fits into the genre of Holocaust novel. The novel tells a tragic story happened in the large historical context of the Second World War, depicting pure friendship between two 8-year-old boys, Bruno, the son of the Nazi extermination camp's commandant, and a Jewish inmate Shmuel.

Famous writer Liu Xiujuan claims that For literature work the portrayal of death is even more difficult when "the subject of war" and "children readers" collide. It is already painstaking for writers to handle the depiction of wars, since they have to face numerous difficulties brought by the combination of adherence to historical facts and high writing techniques. However, it is even more complicated to translate complex history into a concise and readable narrative for children. Writers ought to narrate a story which is supposed to be filled with cruelty and bloodiness, in a way that does not stimulate the senses but touch the heart (61).

It is worth noticing that, by employing children's perspective, Boyne not only successfully achieves this standard put forward by Liu, but also manages to bring a thought-provoking reading experience for adult readers.

The most prominent feature of this novel is that, all images and events associated with the gloom of warfare and death are manifested from Bruno's perspective. Covered by childish language and euphemism, cruelty of massacre and war is almost "invisible" for young readers, but still perceivable and even more suffocating when it comes to adult readers.

Firstly, the terms related to the horror of Nazi's concentration camp are always mispronounced and misunderstood. "The Fury" and "Out-With", for instance, indicates Bruno's naive interpretation of the words "Auschwitz" and "Fuhrer". When Bruno first see the camp, he is uncertain whether it is a farm or some "modern types of houses" or "the countryside... this is where the people live and work and send all the food to feed us" (Boyne 33). And strangely the farmers there are all in "striped pyjamas" (prison clothes) (Boyne 38).

Moreover, Bruno is characterized by ignorant and childish way of thinking, always being unaware of the fact. In 
Bruno's eyes, he lives in a warm family, and naturally he believes that his loving father, an absolute role model, who does important jobs and wears "impressive uniforms", would also be nice to other people. And it is common for a child to be in defense of his father, though having no idea what his father's job entails.

"There aren't any good soldiers," said Shmuel.

"Of course there are," said Bruno.

"Who?"

"Well, Father, for one," said Bruno. "That's why he has such an impressive uniform and why everyone calls him Commandant and does whatever he says. The Fury has big things in mind for him because he's such a good soldier."

"There aren't any good soldiers," repeated Shmuel.

"Except Father," repeated Bruno." "Father was Father, and Bruno didn't think it was right for someone to say something bad about him" (Boyne 140).

Bruno is even unaware of his approaching to death. When they are led into a gas chamber, Bruno is "unable to understand the sense of all this, but he assumed that it had something to do with keeping the rain out and stopping people from catching colds" (Boyne 213).

\subsubsection{Influence of Boyne's portrayal}

Although the children's perspective ostensibly makes the story less complicated, the novel still manages to penetrate into the depth of human nature. Claire King highly appreciates the view of children, "What I love about child narrators is the way they question the things that we take for granted, and take for granted the things we question." In Bruno's eyes, there is no war, no inmate, no concentration camp, just people who can make friends with.

The holocaust remains incomprehensible for the two innocent victims. And younger readers may also be unaware of the cruelty of massacre and war concealed by childish narration and euphemism, thus the horror can be largely diminished in their eyes.

However, the narrator allows a mature reader to back-shadow his knowledge into the narrative. (Darius Jackson 144) Adult readers can spontaneously match Bruno's misinterpreted terms with the harsh history, and will be aware of the miserable fate of the boys.

All these suggest that Boyne is writing for a knowing reader. Everything is clear and even more painful for them behind the euphemistic language. The audience are driven to perceive the suffocating tension in the contrast between innocence and evil, beauty and ugliness. Through the perspective of children, adult readers allow their view of war to transcend the contents merely exist in historical books, they begin to truly pondering about the connotation of warfare. What does war mean for people? Readers become aware that the war is not simply a huge event, but a man-made disaster, which is full of absurdity, brutality, and inhumanity. Boyne tries to convey his idea that men should never descend to inhuman beings.

Furthermore, the death of Bruno carries profound symbolic meaning. Being shielded from the harshest realities of war can not save Bruno, or any other innocent people like him, from violent practices that others inflict upon them. In other words, innocence can not be preserved in an era characterized by the loss of humanity, thus it is doomed to be tainted, like the change of Gretel (Bruno's sister), or destroyed. Boyne presents the readers with the most drastic and sorrowful ending.

In the end of the book, Boyne's meaningful epilogue is in fact addressing to both children and adult readers, and they may interpret it in very divergent ways.

"Of course all this happened a long time ago and nothing like that could ever happen again. Not in this day and age" (Boyne, 216).

Young readers, being unaware of war and death, just like Bruno in the novel, may merely interpret "Nothing more was ever heard of Bruno after that" and "vanished" as a probability that the little hero had lost his way. However, when it comes to adult readers, Jackson claims that "these lines could be read ironically, since any reader with knowledge of postwar history would know that genocides and persecution continue to this day" (140). Nevertheless, the epilogue, in my opinion, is not only a sarcasm, but Boyne's appeal for moral obligation with a frustrated heart.

\section{Conclusion}

By closely examining the two successful crossover fictions, Harry Potter and The Boy in the Striped Pyjamas, it can be observed that they sufficiently demonstrate the significance of presenting the theme of death to readers. Through their unique methods of portrayal, Harry Potter lays emphasis on its guiding function for young readers, while The Boy in the Striped Pyjamas focuses more on inspiring adults. To conclude, death should not be treated as a taboo, and it is the duty for literature to present life and death with humane care as well as profound reflections. 


\section{References}

[1] Tonkin, Boyd. Once Upon a Time in the Marketing Department. The Independent. 6 November. 2002

[2] Maria Nagy. The Child's Theories concerning Death. The Pedagogical Seminary and Journal of Genetic Psychology. 1948; 73: 3-27. DOI: 10.1080/08856559.1948.10533458

[3] Chen Junjun. Out of the Taboo of Death, Comes the Psychological Development - An Analysis of the Concept of Death in Charlotte's Web. Journal of Xi'an Shiyou University (Social Sciences). 2019; 28(06): 108-112.

[4] Stojilkov, Andrea. Life(and)death in 'Harry Potter': The Immortality of Love and Soul. Mosaic: An Interdisciplinary Critical Journal. 2015; 48(2): 133-148.

[5] Rowling, J.K. Harry Potter and the Sorcerer's Stone.

[6] Rowling, J.K. Harry Potter and the Prisoner of Azkaban.

[7] Hiebert Alton, Anne. Playing the Genre Game: Generic Fusions of the Harry Potter Series. Critical Perspectives on Harry Potter. New York: Routledge; 2009.

[8] Svetina, M. Resilience in the context of Erikson's theory of human development. Current Psychology. 2014; 33(3): 393-404.

[9] Zhang Yingming.A Preliminary Study on the Topic of Death in Children's Literature. Foreign Languages and Literature. 2018; (04):172.

[10] Orgelfinger, Gail. J.K. Rowling's Medieval Bestiary. Studies in Medievalism. 2009; 17: 141.

[11] Liu Xiujuan. The difficulty of war-themed children's novels. Literature and Art News, 2015-08-17(005).

[12] Boyne, John. The Boy in the Striped Pyjamas.

[13] King, Claire. Available from: http://bookanista.com/child-narrators-adult-fiction/

[14] Darius, Jackson. I Know It's Not Really True, but It Might Just Tell Us...: The Troubled Relationship between The Boy in the Striped Pyjamas and Understanding about the Holocaust. Holocaust Education: Contemporary Challenges and Controversies, edited by Stuart Foster et al. London: UCL Press; 2020. 